\title{
Acceptability and usage of contraceptive among women of reproductive age group in hilly areas of Garhwal, Uttrakhand, India
}

\author{
Navajyoti Bora ${ }^{1}$, Santosh kumar $^{2}$ \\ ${ }^{l}$ Associate Professor, Department of Obstetrics \& Gynaecology VCSGGMS\& RI, Srinagar,Uttarakhand,India \\ ${ }^{2}$ Assistant Professor, Department of Community Medicine, VCSGGMS\&RI, Srinagar,Uttarakhand,India
}

\begin{abstract}
Socio economic development of nation is intricately related to family planning policy. The reports of rise in contraceptive practices are not in correspondence with the similar decrease in the population number, therefore there is an urgent need to assess the cause of discrepancy. The present study is an effort to assess the knowledge, attitude and practice of contraception among Garhwal (Uttrakhand) population. The objective of the study was to assess the knowledge and acceptability of contraceptives among the women of reproductive age group.This is a cross sectional study based on sample of 418 married women of reproductive age group of 15-49 in the tertiary care hospital of Srinagar Garhwa,l Uttrakhand,India .Participants were interviewed for the knowledge and utilization of contraceptives. Throughout the study we observed that great awareness about the various contraceptive measures maximum being about sterilization (100\%) irrespective of age. However the usage (77\%) is not in proportion to awareness, and is highly influenced by the educational status, being $100 \%$ in graduates and postgraduates and least among high school dropouts (3.2\%)
\end{abstract}

Keywords: Sterilization, Reproductive age group, Utilization

\section{Introduction}

The reports of rise in contraceptive practices are not in correspondence with the similar decrease in the population number, therefore there is an urgent need to assess the cause of discrepancy.The present study is an effort to assess the knowledge, attitude and practice of contraception among Garhwal population.

The acceptance of contraception by a couple is governed by various socio-cultural factors, such as religion (NFHS: 1998-99, 2002) and education of husband and wife (Coale, 1965; Berelson, 1976; Chachra and Bhasin, 1998; Bhasin and Nag, 2002). In India, the states with greater contraceptive use have generally achieved a more advanced state of socioeconomic modernization (Srinivasan et al., 1984). This achievement has generated the observed higher levels of motivation. Mass media also plays an important role in promotion and acceptability of contraception (Bhat, 1996; Ramesh et al., 1996). While, spousal communication increases the likelihood of contraceptive use (Lasee and Becker, 1997; Kamal, 1999; Ghosh, 2001). Son preference, women's age, literacy, number of living children, number of living sons also influences contraceptive use (Gandotra and Das, 1990; Levine et al., 1992; Bora and Jha, 2001). Couples with fewer sons are more likely to continue having more children, besides, have shorter birth intervals and are also less probable to use contraception or sterilization.

In 1965-2009 period contraceptive uses has more then tripled (from 13\% of married women in 1970 to $48 \%$ in 2009 ) and fertility rate halved (from $5.7 \%$ to $2.6 \%$ ) In $2009,48.3 \%$ of married women are estimated to use contraceptive methods and about $3 / 4^{\text {th }}$ of these were using female sterlisation and $3 \%$ were using condoms. Female literacy is strong predictor of use of contraception. An expanded reproductive health program must include access to safe, effective and affordable methods of family planning for both male and female, informed choice in contraceptive methods and high quality supply.

\section{Materials and Methods}

This is a cross sectional study based on the sample of 418 conducted in Department of Obstetrics and Gynecology,VCSGGMSRI, a tertiary care hospital of the hilly areas of Garhwal.

\section{SAMPLE SIZE}

The sample size of proposed study was calculated by the following formula $S=X^{2} N P(1-p) / D^{2}(n-$ $1)+X^{2} p(1-P)$ where

$\mathrm{X}^{2}$-Table value of chi square

$\mathrm{P}=$ population proportion

$\mathrm{N}=$ population size

$\mathrm{D}=$ degree of freedom 
All the married women of reproductive age group were interviewed on alternate OPD days .Systemic random sampling was used for the required sample size. Semi structured pretested interview schedule were used. The participants have been given free opportunity to choose any type of contraceptive method during the interview, and the possible overlapping in the results could be because of this reason. The data was collected, tabulated and analysed in the microsoft excel software. Appropriate statistical tests were used by using SPSS statistical software.

\section{Results}

Table 1:Acceptability of Family Planning methods

\begin{tabular}{|l|l|l|}
\hline Age in year & $\begin{array}{l}\text { Acceptability of family } \\
\text { planning method }\end{array}$ & Percentage \\
\hline $15-19(\mathrm{n}=25)$ & 22 & 88.0 \\
\hline $20-24(\mathrm{n}=92)$ & 76 & 82.6 \\
\hline $25-29(\mathrm{n}=110)$ & 101 & 91.8 \\
\hline $30-34(\mathrm{n}=90)$ & 81 & 90.0 \\
\hline $35-39(\mathrm{n}=65)$ & 55 & 84.6 \\
\hline $40-44(\mathrm{n}=22)$ & 15 & 68.1 \\
\hline $45-49(\mathrm{n}=14)$ & 8 & 57.1 \\
\hline TOTAL $=418$ & 358 & 85.6 \\
\hline
\end{tabular}

It was observed that majority(91\%) of the study participants from the 25 to 29 year of age group were utilizing the contraceptive methods. while contraceptive use was least among the age group of 45 to 49 years.

Table 2: Distribution of women who ever married having knowledge of any contraceptive by age and specific methods

\begin{tabular}{|c|c|c|c|c|c|c|c|c|c|}
\hline \multirow{2}{*}{$\begin{array}{l}\text { Contraceptive } \\
\text { Methods }\end{array}$} & \multicolumn{7}{|c|}{ Age In Years } & \multirow{2}{*}{$\begin{array}{l}\text { Total } \\
\text { No. }\end{array}$} & \multirow[t]{2}{*}{$\%$} \\
\hline & $\begin{array}{l}15-19 \\
n=25\end{array}$ & $\begin{array}{l}20-24 \\
n=92\end{array}$ & $\begin{array}{l}25-29 \\
n=110\end{array}$ & $\begin{array}{l}30-34 \\
n=90\end{array}$ & $\begin{array}{l}35-39 \\
n=65\end{array}$ & $\begin{array}{l}40-44 \\
n=22\end{array}$ & $\begin{array}{l}45-49 \\
n=14\end{array}$ & & \\
\hline Pills & 23 & 89 & 109 & 88 & 55 & 20 & 9 & 393 & 94 \\
\hline IUD & 18 & 76 & 101 & 85 & 62 & 21 & 6 & 369 & 88.2 \\
\hline Condom & 22 & 84 & 106 & 86 & 64 & 18 & 7 & 387 & 92.5 \\
\hline Injectables & 3 & 17 & 18 & 15 & 7 & 2 & 1 & 63 & 15 \\
\hline Abstinence & 15 & 60 & 70 & 46 & 32 & 11 & 4 & 238 & 56.9 \\
\hline Sterilization & 25 & 92 & 110 & 90 & 65 & 22 & 14 & 418 & 100 \\
\hline
\end{tabular}

The awareness among the women in this region and age group who were married has been listed in Table 2 and their awareness about the different measures of contraception were questioned. Among the various contraceptives known to the women awareness about the sterilization found be highest(100\%) followed by pills and lowest $(15 \%)$ awareness was about injectable contraceptives. IUCD and condom were moderately known to people (88 and $92.5 \%$ ).

Table 3:Percent distribution of married women, aged 15-49 years by main source of family planning information

\begin{tabular}{|l|l|l|}
\hline Source of FP information & No. & Percent \\
\hline Relatives/Friends & 96 & 22.9 \\
\hline Doctors/Nurses/FP workers & 120 & 28.7 \\
\hline TV/Radio/Other mass media & 370 & 88.5 \\
\hline
\end{tabular}

The source of information was not exclusive and the number of overlapping source of information are present for the same subject. It was found that mass media played the largest role in creating awareness among the study group as $88.5 \%$ of the females accepted the mass media as their principal source of information . The health care workers, doctors and nurses formed a minor section of information $(28.7 \%)$. This lower source of information could be because of hard access and availability of health facilities at the hilly region and the information gathered from friends and relatives is also found to be less $(22.9 \%)$ The source of information was not exclusive and a number of overlapping source of information are present for the same subject.

The acceptability of contraceptive measures in different age groups has been listed in Table 4 and the highest acceptability rate is seen in the age group of $25-29 \mathrm{yrs}$, with only an acceptability rate of $57 \%$ in the age 
group of 45-49yrs, which is fairly low as compared to other age groups as within 30-34 yrs (90\%), 15-19 yrs $(88 \%)$, and $35-39 y r s(84.6 \%)$

Table 4:Distribution of married women towards acceptability of family planning messages based on educational background

\begin{tabular}{|l|l|l|l|l|l|}
\hline \multirow{2}{*}{ Education } & \multicolumn{4}{|l|}{ Acceptability of family planning message } & \multirow{2}{*}{ No. Of Women } \\
\cline { 2 - 5 } & Yes & No & Yes \% & No \% & \\
\hline Illiterate & 128 & 28 & 82.1 & 17.9 & 156 \\
\hline Primary School & 106 & 14 & 88.3 & 11.7 & 120 \\
\hline Middle School & 50 & 6 & 89.2 & 10.8 & 56 \\
\hline High School & 25 & 2 & 92.6 & 7.4 & 27 \\
\hline Higher Secondary & 30 & 1 & 96.8 & 3.2 & 31 \\
\hline Graduation & 16 & 0 & 100.0 & 0.0 & 16 \\
\hline Postgraduation & 12 & 0 & 100.0 & 0.0 & 12 \\
\hline TOTAL & 367 & 51 & - & - & $\mathbf{4 1 8}$ \\
\hline
\end{tabular}

The acceptability of contraceptive measures was found to be highest(100\%) among those were graduate and above and least among the illiterate. This could be because of higher exposure to mass media and their peer group. This percentage of acceptability of contraceptive at the remote area of hill is really significant where acceptability is $82.1 \%$ even among the illiterate population.

Table 5:Distribution of currently married women aged 15-49 years who are current users of modern contraceptive methods by specific methods and source of acquisition

\begin{tabular}{|l|c|l|l|l|l|c|}
\hline $\begin{array}{l}\text { Contraceptive } \\
\text { methods }\end{array}$ & \multicolumn{5}{|c|}{ Source of acquisition } & Total \\
\hline & $\begin{array}{l}\text { Govt. } \\
\text { Hospitals }\end{array}$ & $\begin{array}{l}\text { PHC } \\
\text { Hospitals }\end{array}$ & $\begin{array}{l}\text { Private } \\
\text { Doctors }\end{array}$ & $\begin{array}{l}\text { Private } \\
\text { Hospitals }\end{array}$ & $\begin{array}{l}\text { Drug } \\
\text { stores }\end{array}$ & No. \\
\hline Pills & 30 & 31 & - & 7 & - & 68 \\
\hline IUD & 39 & 26 & - & 5 & - & 70 \\
\hline Condoms & - & 11 & - & - & 37 & 48 \\
\hline $\begin{array}{l}\text { Female } \\
\text { Sterilization }\end{array}$ & 51 & - & 3 & - & - & 54 \\
\hline
\end{tabular}

It seems that the governmental policies of contraceptive measures are more accessible in these regions as compared to other regions of the nation as the source of acquisition for majority of the population is through Government channels. $94.4 \%$ of the sterlisation procedures are performed in the Government setups and only $5.5 \%$ in the private clinics. A significant number of subjects are not using any contraceptive measures inspite of having adequate knowledge, awareness and need to use them.

Table 7:Percent distribution of currently married women who never used any contraception by main reason for not using any

\begin{tabular}{|l|c|c|}
\hline Reason for non-use & Number & Percent \\
\hline Want more children & 37 & 40.3 \\
\hline Menopausal & 2 & 2.1 \\
\hline Health does not permit & 17 & 18.4 \\
\hline Worry about side-effects & 24 & 26.1 \\
\hline Difficult to get pregnant & 3 & 3.2 \\
\hline Religious opposition & 7 & 7.6 \\
\hline Opposition of husband & 2 & 2.1 \\
\hline TOTAL & 92 & 100 \\
\hline
\end{tabular}

It is obvious that need for more children is the major reason $(40.3 \%)$ for not using any contraceptive despite the knowledge about their existence. Worry about side-effects is the second most important reason. 


\section{Discussion}

According to the observation the married women in reproductive age group residing in the hilly regions of Garhwal are aware about the need for contraceptive measures as about $92 \%$ of the women showed awareness about the measures. This is in correspondence with the study done by Manisha and $\operatorname{Kumar}(10)$ done in 2009 in Kanpur where awareness was $96 \%$.Almost all the women had knowledge about the terminal methods $(100 \%)$ followed by OCPs $(94 \%)$,condoms $(92.5 \%)$ and only $15 \%$ had knowledge about injectables. However the awareness rates are higher than that of Gorakhpur according to the study conducted by Srivastav et al (2) where highest rate are of sterilisation $98.6 \%$ followed by OCPs $50 \%$ and only $8.6 \%$ had knowledge about injectable contraceptives. The mass media played the major role in creating the contraceptive awareness where $88.5 \%$ of the females owed their contraceptive awareness to it and only $22.9 \%$ were enlightened about the measures by friends and relatives . The acceptability of family planning measures is found to be greater among the younger age group. $91.8 \%$ of females within $25-29$ yrs of age readily accepted contraceptive measures.

Education played a major role in broadening the perspective of the females as $100 \%$ of the graduates and postgraduate females had a acceptable attitude towards family planning while $82.1 \%$ of the illiterate females had inclination towards acceptance. This is in wide variation from the study conducted by Jyoti , Meena et al (10) in Delhi where only $52.4 \%$ of the illiterate females accepted the family planning measures. However the usage rates of contraceptive measures are not in correspondence with the awareness rate where the highest user rates are seen among $20-24$ yrs $(84 \%)$ followed by $83.3 \%$ in $30-34$ yrs age group. The greatest number of nonusers lie in $45-49 \mathrm{yrs}$ of age where rates are as low as $50 \%$. Thus it is evident that the menopausal women are the main nonusers probably because of less probability of conceiving. The major contraceptive in use is IUCD (26.1\%) followed by pills $(25.3 \%)$,sterilization $(20.1 \%)$ and the lowest being injectables $(1 \%)$. This is contradictory to the study of Bhasin in 2005(12) where condom usage was $33.4 \%$ followed by sterilisation $27.3 \%$ and then OCPs $19 \%$ followed by IUCD . The principal reason for discontinuation of contraceptive practices among this population is need for more children (40.3\%) followed by the worries about the side effects (26.1\%) and $18.4 \%$ of the women stated that their health does not permit the usage. Only $2.1 \%$ of women faced the spouse opposition while $7.6 \%$ stated that contraceptive usage is against their religious practice. According to Chadwik(13) fear of side effects and want for more children is the principal reason for the discontinuation. However Rama et al(11)in 2000 and Banerjee in 2004 have stated the illiteracy as the major cause . They stated that need for contraception was not felt by $36.92 \%$ of women while only $13.84 \%$ of the women avoided the contraceptive usage because of eagerness for more children. Rama et al (11) also found the need for more children as the major cause $39 \%$ ) for discontinuation of contraceptives. The opposition from family members prevented $26 \%$ of females to use contraception.

\section{Conclusion and Recommendation}

The utilization of contraceptive among the women of this hilly area of Garhwal region is low as compared to their awareness .It could be due to unavailability and poor access of contraceptives in remote and hard to reach areas in hilly region .The health administration of the state should make available the contraceptives to every Subcentres and Primary health centres of this region.

\section{References}

[1] Dabral S,Malik S,Department of Anthropology,University of Delhi, Delhi 110 007, India. hum ecol., 17(1):1-12(2005)

[2] Reena S,Dhirendra Kumar S,Radha S, Kumkum S, Neela S,Contraceptive knowledge attitude and practice (KAP) survey. J Obstet Gynecol India 2005; 55: (6 )550

[3] Tripathi R,Rathore AM,Sachdeva J. Emergency contraception: Knowledge, attitude, and practices among health care providers in North India.Journal of Obstetrics and Gynaecology Research 2003;29( 3):142-146.

[4] Roy M,Lahiri BC,Ghosh BN.KAP study on MTP acceptors and their contraceptive practice. Indian J Public Health.; 1978: 22(2) 189-96.

[5] Chopra I S,Dhaliwal L.Attitude and practice of contraceptive in urban population of North India.Arch Gynecol Obstet; (2010):281:273-277

[6] Sentumbwe S, Lyomoki SW, Guwattude D. Makerere. KAP study about STDs \& family planning among rural youth in Uganda.African J Family Planning. 1994 ,7-12; 10:68

[7]. Qayed M. KAP Study on Reproductive Health among Adolescents and Youth in Assiut Governorate, The Research Management Unit of The National Population Council, Cairo, Egypt 1998. Available at http://pdf.usaid.gov/pdf docs/PNACE053.pdf

[8]. Schenk K. Emergency Contraception The UK experience. J Fam Plan Reprod Health Care 2003;29:35-40 doi:10.1783/14711890310 1197223

[9] Dabral S,Malik SL.Demographic Study of Gujjars of Delhi:IV. KAP of Family Planning Department of Anthropology, University of Delhi. J. Hum. Ecol. 16(4): 231-237 (2004).

[10] Kumar M, Sumedha S ,Dhalewal V, Sharma J. Contraceptive use among low income urban married woman in India. The Journal of Sexual Medicine Volume 8, Issue 2;376-382, February 2011

[11] Kumar R,Gopal S.Husband-wife communications and fertility in a sub-urban community exposed to family planning. Journal of Family Welfare. 1972; 18(3):30-36

[12] Bhasin M.K, Nair S. A Demographic profile of the people of Jammu and Kashmir: Family Planning. Journal of Human Ecology.13: $147-166$ (2002) 
[13] Fakeye O, O Babaniyi. Reasons for non-use of family planning methods at Ilorin, Nigeria: Male opposition and fear of methods. Tropical Doctor 1989; 19(3): 114-7.

[14] Fakhr El-Islam M,Malasi TH,Abu-Dagga SL. Oral contraceptives, sociocultural beliefs and psychiatric symptoms. Social Science and Medicine.1989; 27(9): 941-5.

[15] Simmons G. B, Simmons RS, Mishra BD, Ashraf A. Organization for change: A systems analysis of family planning in rural India. Ann Arbor Michigan: Center for Population Planning, University of Michigan School of Public Health.

[16] Mishra VK,Robert D.Rutherford P,Nair S.Reasons for discontinuing and not intending to Use Contraception in India National Family Health Survey Subject Reports Number 13; June 1999

[17] Park K. Park's textbook of Preventive and Social Medicine. $17^{\text {th }}$ edn. Jabalpur. Banarasidas Bhanot. 2002:325-58.

[18] Daryle W,Robert V.Determining sample size for research activities .Education and Psychological Measurement 1970;30.607-610 